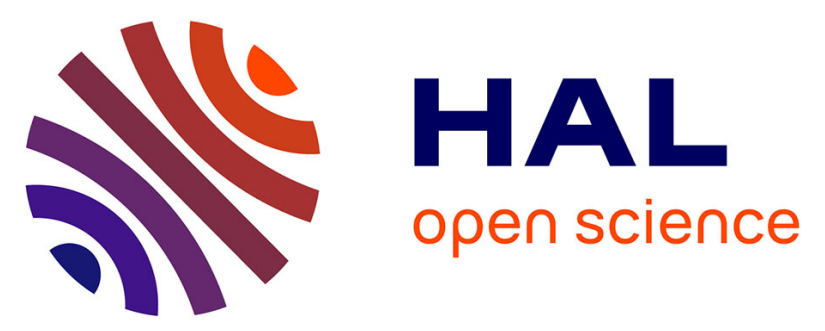

\title{
Immunocreative gonadotropin-releasing hormone-like material in the brain and the pituitary gland during the periovulatory period in the brown trout (Salmo trutta L.): Relationships with the plasma and pituitary gonadotropin
}

Bernard Breton, A. Motin, Roland Billard, Olivier Kah, S. Geoffre, G. Precigoux

\section{- To cite this version:}

Bernard Breton, A. Motin, Roland Billard, Olivier Kah, S. Geoffre, et al.. Immunocreative gonadotropin-releasing hormone-like material in the brain and the pituitary gland during the periovulatory period in the brown trout (Salmo trutta L.): Relationships with the plasma and pituitary gonadotropin. General and Comparative Endocrinology, 1986, 61, pp.109-119. 10.1016/00166480(86)90255-8 . hal-02728728

\section{HAL Id: hal-02728728 \\ https://hal.inrae.fr/hal-02728728}

Submitted on 2 Jun 2020

HAL is a multi-disciplinary open access archive for the deposit and dissemination of scientific research documents, whether they are published or not. The documents may come from teaching and research institutions in France or abroad, or from public or private research centers.
L'archive ouverte pluridisciplinaire HAL, est destinée au dépôt et à la diffusion de documents scientifiques de niveau recherche, publiés ou non, émanant des établissements d'enseignement et de recherche français ou étrangers, des laboratoires publics ou privés.

\section{()(1)(2)}

Distributed under a Creative Commons Attribution - ShareAlikel 4.0 International 


\title{
Immunoreactive Gonadotropin-Releasing Hormone-like Material in the Brain and the Pituitary Gland during the Periovulatory Period in the Brown Trout (Salmo trutta L.): Relationships with the Plasma and Pituitary Gonadotropin
}

\author{
Bernard Breton, ${ }^{* 1}$ Agnès Motin, ${ }^{*}$ Roland Billard,* Olivier Kah, $\dagger$ \\ Serge Geoffre, $*$ and Gilles PrecigouX $\$$ \\ *Laboratoire de Physiologie des Poissons, INRA, Campus de Beaulieu, Rennes 35042, France; †Laboratoire \\ de Physiologie des interactions cellulaires; and $\$$ Laboratoire de Cristallographie et Physique cristalline, \\ Université de Bordeaux I, Talence, 33405 France
}

Accepted June 24, 1985

\begin{abstract}
In fish there are few data on the gonadotropin-releasing hormone (Gn-RH) neurosecretory activity, which could explain long- and short-term variations of the gonadotropin secretion. There is no biological species specificity between mammal and fish Gn-RH; although there is a structural difference, they are, on the contrary, characterized by a high immunological specificity which does not allow measurement of fish Gn-RH using radioimmunoassay for LH-RH. We have synthesized salmon Gn-RH according to the formula recently proposed by Sherwood (N. Sherwood, L. Eiden, M. Brownstein, J. Spies, J. Rivier, and W. Vale, 1983. Proc. Natl. Acad. Sci. USA 80, 2794-2798). Its activity has been tested by its ability to stimulate the gonadotropin hormone $(\mathrm{GtH})$ secretion in vivo in testosteroneimplanted juvenile rainbow trout, and for the recognition of synthesized Gn-RH (s-Gn-RH) perykaria by a specific antibody raised against the s-Gn-RH in regions of the brain described as containing LH-RH immunoreactive-like material. A radioimmunoassay has been developed for the salmon Gn-RH, and its specificity to measure trout Gn-RH has been tested. Using this assay, the brain and pituitary Gn-RH contents have been measured throughout the final phases of maturation and ovulation. Brain Gn-RH increases from the end of vitellogenesis ( $8.9 \pm 0.76 \mathrm{ng} /$ brain) to ovulation (more than $15 \mathrm{ng} / \mathrm{brain})$. Pituitary $\mathrm{Gn}-\mathrm{RH}$ is lower $(1.58 \pm 0.69 \mathrm{ng} /$ pituitary $)$ at the end of vitellogenesis and follows a similar profile as in the brain, except for a significant decrease just prior the beginning of oocyte maturation. The correlations between Gn-RH levels and GtH pituitary and plasma levels show that total brain $\mathrm{Gn}-\mathrm{RH}$ is never correlated to the $\mathrm{GtH}$, suggesting that the increase in the brain $\mathrm{Gn}$ RH content is related to a Gn-RH system closcly related to maturation and ovulation, which remains to be investigated. On the contrary, pituitary Gn-RH levels are well correlated with pituitary and plasma GtH levels, indicating that pituitary $\mathrm{Gn}-\mathrm{RH}$ levels might represent a good index of the Gn-RH neurosecretory activity in the fish hypothalamohypophysial complex, given the absence of a portal system in teleost. 1986 Academic Press, Inc.
\end{abstract}

Although there is much quantitative information about the endogenous levels of plasma and pituitary GtH in teleost fish, and especially in salmonids, it is still difficult to correlate them with variations of the hypophysiotropic activity in the central nervous system, whose secretions are the

${ }^{1}$ To whom correspondence should be addressed. primary chemical links between the fish and its environment for the control of most of the reproductive processes (gametogenesis, ovulation, spawning, reproductive behavior). It has been known for a long time that mammalian $\mathrm{LH}-\mathrm{RH}$ and fish gonadotropin-releasing hormone $(\mathrm{Gn}-\mathrm{RH})$ are nearly similar regarding their biological activity (Breton et al., 1972; Breton and Weil, 
1973; King and Millar, 1980). This property has been used for the development of a bioassay to measure the Gn-RH activity in salmonids (Crim and Evans, 1980), but this method, unlike similar in vitro determinations in rats, for example, is not sensitive enough and too complex to measure the Gn-RH content in isolated fish brain and pituitary in numerous samples. Only limited attempts have been made to develop a radioimmunoassay for fish $\mathrm{Gn}-\mathrm{RH}$ because of the immunological species specificity betwecn fish and mammalian releasing hormone (King and Millar, 1979; 1980), and few have been successful (Dufour, et al., 1982; Schreibman, et al., 1983). The aim of this study was to develop a specific radioimmunoassay for salmonid Gn-RH after the determination of its structure (Sherwood et al., 1983) and to apply it to the determination of Gn-RH content in the brain and pituitary of the brown trout during the final stages of maturation.

\section{MATERIALS AND METHODS}

Peptide synthesis has already been described (Breton et al., 1984), and its homogeneity was assessed after high-pressure liquid chromatography with a mixture of methanol-water-trifluoracetic acid as mobile phase $(50-50-0.1)$

In addition, the characterization of the newly synthesized peptide was pursued by testing its ability to stimulate the in vivo GtH secretion and after identification of the brain structure reacting with an antibody raised against the synthesized Gn-RH (s-Gn-RH).

1. Biological activity of the synthesized Gn-RH. Biological activity was determined in May in $60 \mathrm{-g}$ immature rainbow trout pretreated by intraperitoneal testosterone implants to stimulate pituitary GtH synthesis (Crim and Evans, 1980; 1981). Testosterone Silastic implants $(100 \mu \mathrm{g} /$ fish) were set up 3 weeks before the intraperitoneal administration of Gn-RH. Six groups were constituted (Table 1).

Blood was sampled with heparinized syringes from a caudal vessel at 0,5 , and $24 \mathrm{hr}$ after the beginning of the experiment. After centrifugation, plasma was preserved frozen until determination of $\mathrm{GtH}$ content by radioimmunoassay (Breton et al., 1971, 1983).

2. Immunocytochemical localization of Gn-RH. The similarity of the synthetic Gn-RH to a biological peptide was also established by an immunocytochemical technique testing the ability of an antibody raised against the s-Gn-RH to recognize nervous structures containing a $\mathrm{LH}-\mathrm{RH}-\mathrm{like}$ factor within the trout brain. The brains and pituitaries of immature rainbow trout were dissected and fixed for $1 \mathrm{hr}$ in $4 \%$ paraformaldehyde in $0.1 \mathrm{M}$ phosphate buffer, pH 7.6. After rinsing, they were immersed overnight in $0.1 \mathrm{M}$ phosphate buffer containing $12 \%$ sucrose. The sections were processed by the PAP technique, the antibody being diluted at $1 / 2000$. The link antibody and the PAP complex (DAKO, Denmark) were diluted 1/200 and $1 / 600$, respectively. The peroxidase activity was visualized using 3-3'tetrahydrochloride diaminobenzidine (Sigma) and hydrogen peroxide.

3. Radioimmunoassay procedure. The acquisition of antibodies, the radioiodination, and purification technique have been previously described (Breton et al., 1984). After tracer purification by polyacrylamide gel electrophoresis, the degree of iodination (iodine molecules fixed on the tyrosine group) was determined according to Caraty et al. (1980). The labeled s-GnRH was pepsin digested for $24 \mathrm{hr}$ at $37^{\circ}$. The digested peptide was submitted to thin-layer chromatography on silica gel (Merck kiesegel $60 \mathrm{~F} 254$ ) in an ethyl acetate, methanol $2 M, \mathrm{NH}_{4} \mathrm{OH}$ system (5-2-1) in the presence of 3-monoiodo-L-tyrosine (MIT) and 3,5diiodo-tyrosine (DIT) as carriers. After migration, the spots were revealed by ninhidrin, scanned on a radiochromatogram scanner, and those corresponding to the radioactive MIT and DIT were aspirated and counted in a gamma counter.

The specificity of the assay to recognize s-Gn-RH was partially tested by measuring the cross reaction between the labeled s-Gn-RH and antibodies directed against mammalian LH-RH and bird Gn-RH (GIn ${ }^{8}$ $\mathrm{LH}-\mathrm{RH}$ ), and by studying the ability of brain and pituitary extracts, $\mathrm{LH}-\mathrm{RH}$ and $\mathrm{LH}-\mathrm{RHa}$ (D-Ala ${ }^{6}-\mathrm{Des}-$ Gly ${ }^{10} \mathrm{LH}-\mathrm{RH}$ ) to compete the binding of $\mathrm{s}-\mathrm{Gn}-\mathrm{RH}$ to its specific antibody.

4. Collection of samples. The experiment was conducted on a group of 3-year-old female brown trout. Between November 16 and 24, they were checked three times for the detection of their stage of maturity, as described earlier (see Fig. 5) (Jalabert and Breton, 1980).

Some fish were kept for one additional month after ovulation, but were not stripped.

The animals were killed by decapitation, and the entire brain and pituitary were immediately frozen in liquid nitrogen and kept frozen at $-30^{\circ}$ until they were extracted for radioimmunoassay. All these operations were done between 9 and $11 \mathrm{PM}$.

Radioimmunoassay of Gn-RH was performed according to Breton et al. (1984) and of GtH according to Breton et al. (1971).

The results were analyzed using the Student $t$ test, variance analysis, and couple method after logarithmic transformation of the data in order to homogenize the 
TABLE 1

Assay Procedure for the Determination of the Biological Activity of the NEWLY SyNTHESIZED s-Gn-RH

\begin{tabular}{cllc}
\hline Group number & \multicolumn{1}{c}{ Pretreatment } & Treatment & $\begin{array}{c}\text { Number } \\
\text { of fishes }\end{array}$ \\
\hline 1 & Control & Control & 11 \\
2 & Empty implant & Saline & 16 \\
3 & Testosterone implant & Saline & 11 \\
4 & Testosterone implant & s-Gn-RH $50 \mu \mathrm{g} / \mathrm{kg}$ body wt + vehicle & 15 \\
5 & Testosterone implant & s-Gn-RH $100 \mu \mathrm{g} / \mathrm{kg}$ body wt + vehicle & 15 \\
6 & Testosterone implant & s-Gn-RH $500 \mu \mathrm{g} / \mathrm{kg}$ body wt + vehicle & 14 \\
\hline
\end{tabular}

variances. These tests were employed to compare pituitary and plasma $\mathrm{GtH}$, and brain and pituitary $\mathrm{Gn}$ $\mathrm{RH}$. The correlations between $\mathrm{GtH}$ and $\mathrm{Gn}-\mathrm{RH}$ were also calculated for each stage of gonadal development. The parallelism between the competition curves obtained with standards s-Gn-RH and analogs was compared by analysis of covariance of the slopes of the $\operatorname{logit} B / B_{0} \log$ dose curves.

\section{RESULTS}

\section{Gn-RH Synthesis and Biological Activity}

The amino acid analysis of the newly synthesized s-Gn-RH has already been given (Breton et al., 1984).

The HPLC elution profile reveals only one symmetric peak, as shown in Fig. 1.

In fish not implanted with testosterone, pituitary $\mathrm{GtH}$ were, respectively, $2.84 \pm$ $0.5 \mathrm{ng} /$ pituitary in control fish and $15.3 \pm$ $8.5 \mathrm{ng} /$ pituitary in fish receiving an empty implant. In testosterone-implanted fish, pituitary GtH levels markedly increased to $1459 \pm 187 \mathrm{ng} /$ pituitary. Figure 2 shows the profiles of plasma GtH secretion in the experimental groups. At 0 and $5 \mathrm{hr}$, there were no statistical differences between the plasma GtH levels of fish which did not receive Gn-RH treatment (Fig. 2A). After 24 hr GtH plasma levels did not differ in fish from groups 1-3. Gn-RH alone induced a significant increase in the plasma GtH levels at 5 and $24 \mathrm{hr}$ after the injection only in fish receiving the higher $\mathrm{Gn}-\mathrm{RH}$ dosage $(P<0.01)$ (fig. 2B).

The biological activity of the s-Gn-RH was further confirmed in vitro by its ability to stimulate the GtH secretion in trout pituitary cells cultures in a range of dosages between $10^{-6}$ to $10^{-9} M$ (Weil, personal communication).

In the brain, immunoreactive perikarya are located in the olfactory nerves and bulbs, the ventral telencephalon, the preoptic region, and the basal hypothalamus. Immunoreactive fibers are detected in many areas of the forebrain (Fig. 3A). The pituitary gland contains immunoreactive material located in the neurohypophysis bordering the infundibular recess and within digitations entering the proximal pars distalis (Fig. 3B).

\section{Radioimmunoassay}

The mean yicld of the iodination was around $70 \%$, corresponding to a $\mathrm{sp}$ act ranging from 60 to $75 \mu \mathrm{Ci} / \mu \mathrm{g}$ of s-Gn-RH. The profiles of the radioactivity after PAGE of the four most radioactive fractions eluted from the LH-20 column are shown in Fig. 4. The main peaks appear homogeneous, but in all four fractions there is a small, more electronegative component which does not cross react with the antibody raised against s-Gn-RH. The summit of each main peak possesses a greater immunoreactivity than that of the corresponding fraction before electrophoresis; the mean increase in immunoreactivity is around $15 \%$ 


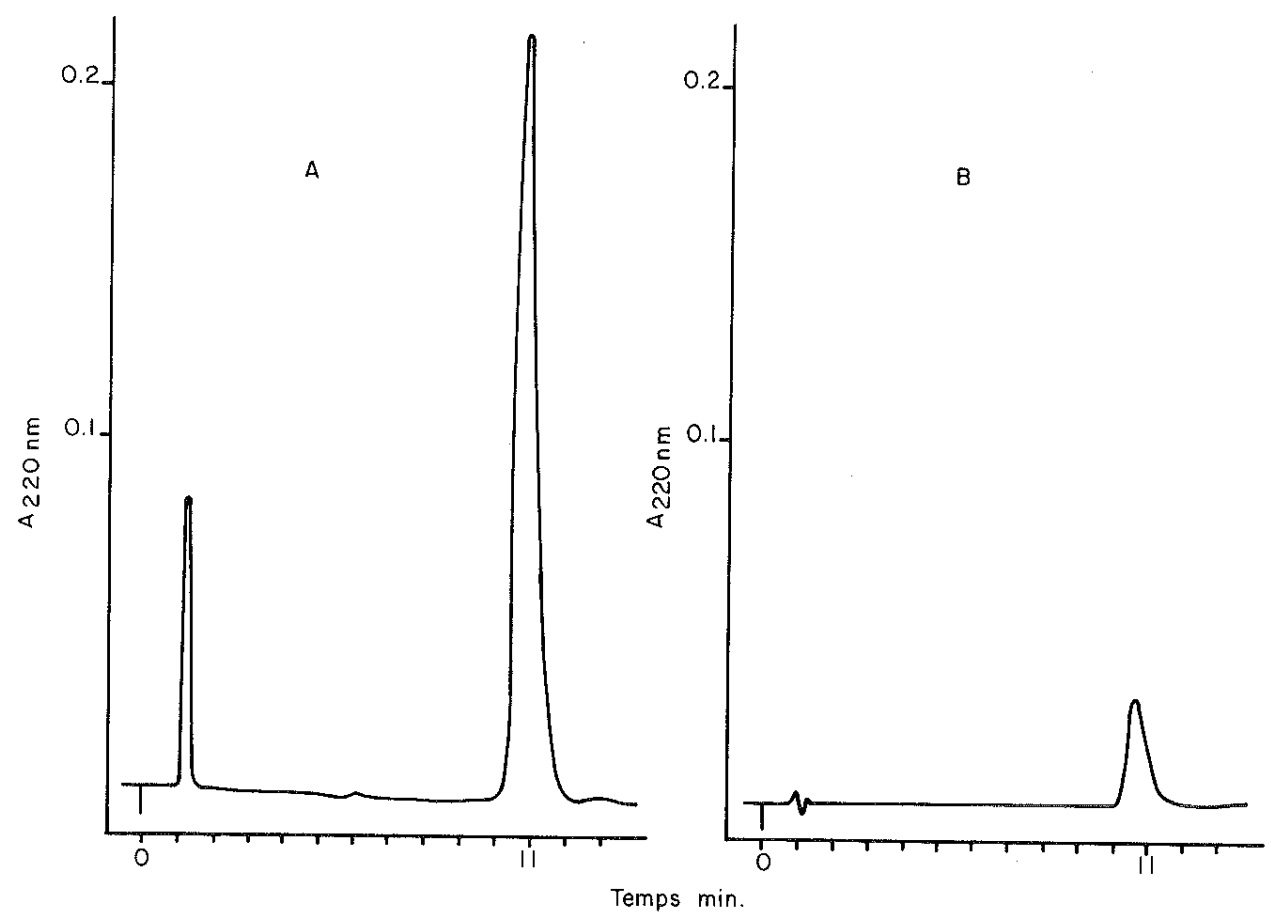

FIG. 1. Profile of Gn-RH elution from reversed-phase HPLC. Column R.P. 18-5 m Bromlee labs 4.6 $\times 25 \mathrm{~cm}$-mobile phase as $\mathrm{MeOH} 50 \% \mathrm{H}_{2} \mathrm{O} 49.9 \%$-TFA $0.1 \%$ Flow $2.5 \mathrm{ml} \mathrm{mn}$. Isocratic elution.

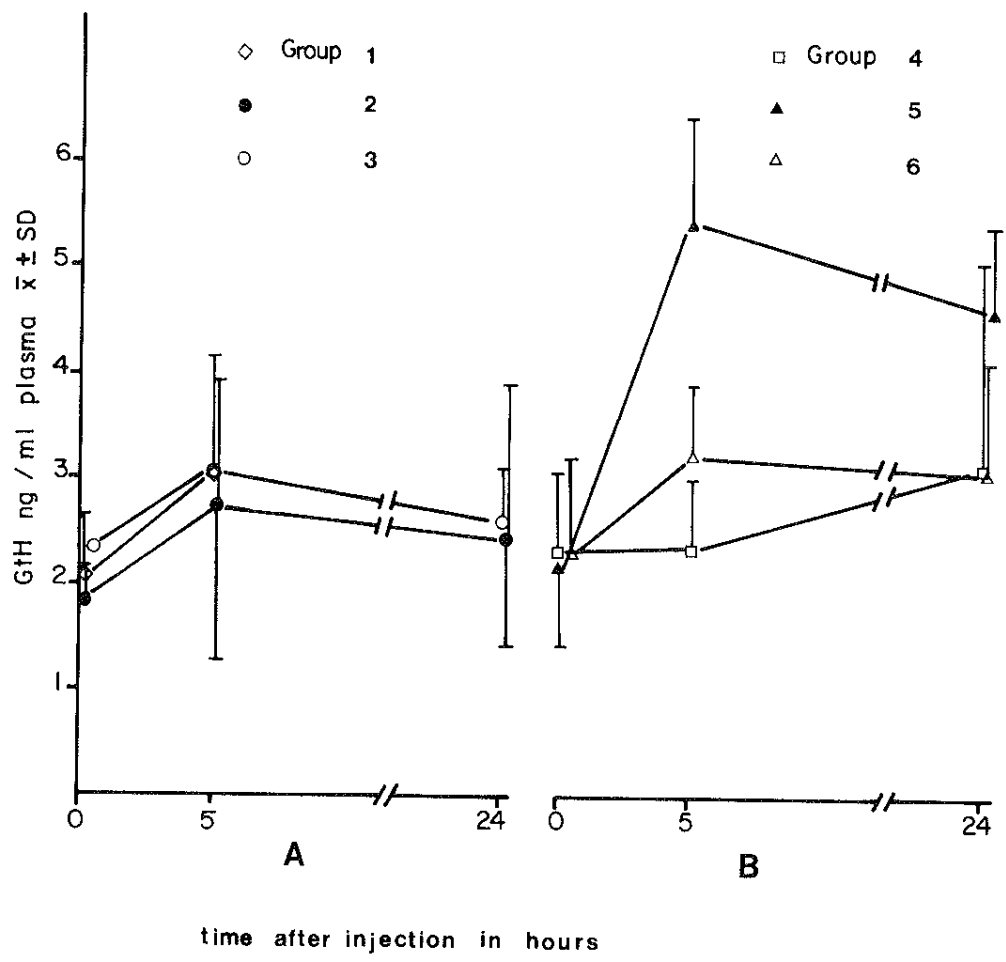

FIG. 2. Evolution of the plasma GtH levels in (A) fish which did not receive s-Gn-RH: $(\diamond)$ control group 1, (O) nonimplant fish + saline, $(O)$ testosterone implanted + saline; and (B) in fish which received s-Gn-RH alone: $\square 50 \mu \mathrm{g} / \mathrm{kg}$ body wt, $\triangle 100 \mu \mathrm{g} / \mathrm{kg}$ body wt, $500 \mu \mathrm{g} / \mathrm{kg}$ body wt. 



FIG. 3. (A) Immunoreactive cell bodies (arrows) in the ventral telencephalon. $\times 240$. (B) Immunoreactive fibers in the pituitary gland at the level of the neurohypophysis (nh) adjacent to the proximal pars distalis $(p d p), v$, third ventricle. $\times 140$.

when the antibody is used as a 1:1000 final dilution.

After pepsin digestion and thin-layer chromatography, the scanning of the plate shows only one peak of radioactivity corresponding to the monoiodotyrosine. After aspiration, the radioactivity was shown to correspond only to the monoiodotyrosine spot.

The tracer diluted in glycerol can be preserved for at least 1 month at $0^{\circ}$ without loss of immunoactivity (Table 2).

The labeled s-Gn-RH never binds more than $7.2 \%$ to eight different anti-LH-RH used at a $10^{-2}$ dilution, and $22.7 \%$ to anti2-10 $\mathrm{LH}-\mathrm{RH}$ used at the same dilution, with which labeled $\mathrm{LH}-\mathrm{RH}$ binds more than $80 \%$. In the same manner, s-Gn-RH binds less than $10 \%$ with the antibody raised against the chicken $\mathrm{LH}-\mathrm{RH}$. The slope of the standard curve was -1.30 and parallel to those obtained in competition studies with brain $(-1.38)$ and brown trout pituitary extracts $(-1.48)$ (Breton et al., 1984), indicating a specificity for the assay of immunoreactive Gn-RH-like materials in these tissues. There was no competitive inhibition by a trout muscle extract, while that by LH-RH and D-Ala ${ }^{6}-$ Des-Gly ${ }^{10}$
LH-RH was not specific. With the latter peptide, $5 \mathrm{ng} /$ tube inhibited only $26 \%$ of the binding of ${ }^{125} \mathrm{I} \mathrm{Gn-RH}$, the same inhibition being produced by $70 \mathrm{pg}$ of s-Gn-RH. Similarly $5 \mathrm{ng}$ of LH-RH inhibited $35 \%$ of the binding compared to $100 \mathrm{pg}$ of s-Gn-RH. The competition obtained with these two peptides was not specific, the slopes of the competition curves being nonparallel to that of the standard curve -0.94 for $\mathrm{LH}-$ RH against -1.30 for $\mathrm{s}-\mathrm{Gn}-\mathrm{RH}$.

The intraassay variability is around $30 \%$ for the standard between 7 and $31 \mathrm{pg} / \mathrm{assay}$ tube and less than $10 \%$ from 62 to $1000 \mathrm{pg} /$ assay tube. These values are higher for the interassay variability ranging from 10 to $25 \%$ between 62 and 1000 pg/assay tube. This part of the curve is generally that which is used for the determination of the s-Gn-RH content in brains and pituitaries, and Table 3 gives the variation coefficients (CV) for five brain samples; they are similar to those obtained with standard, in the same range of concentrations.

\section{GtH and Gn-RH during the \\ Periovulatory Period}

Blood and pituitary GtH contents showed similar variations to those already 


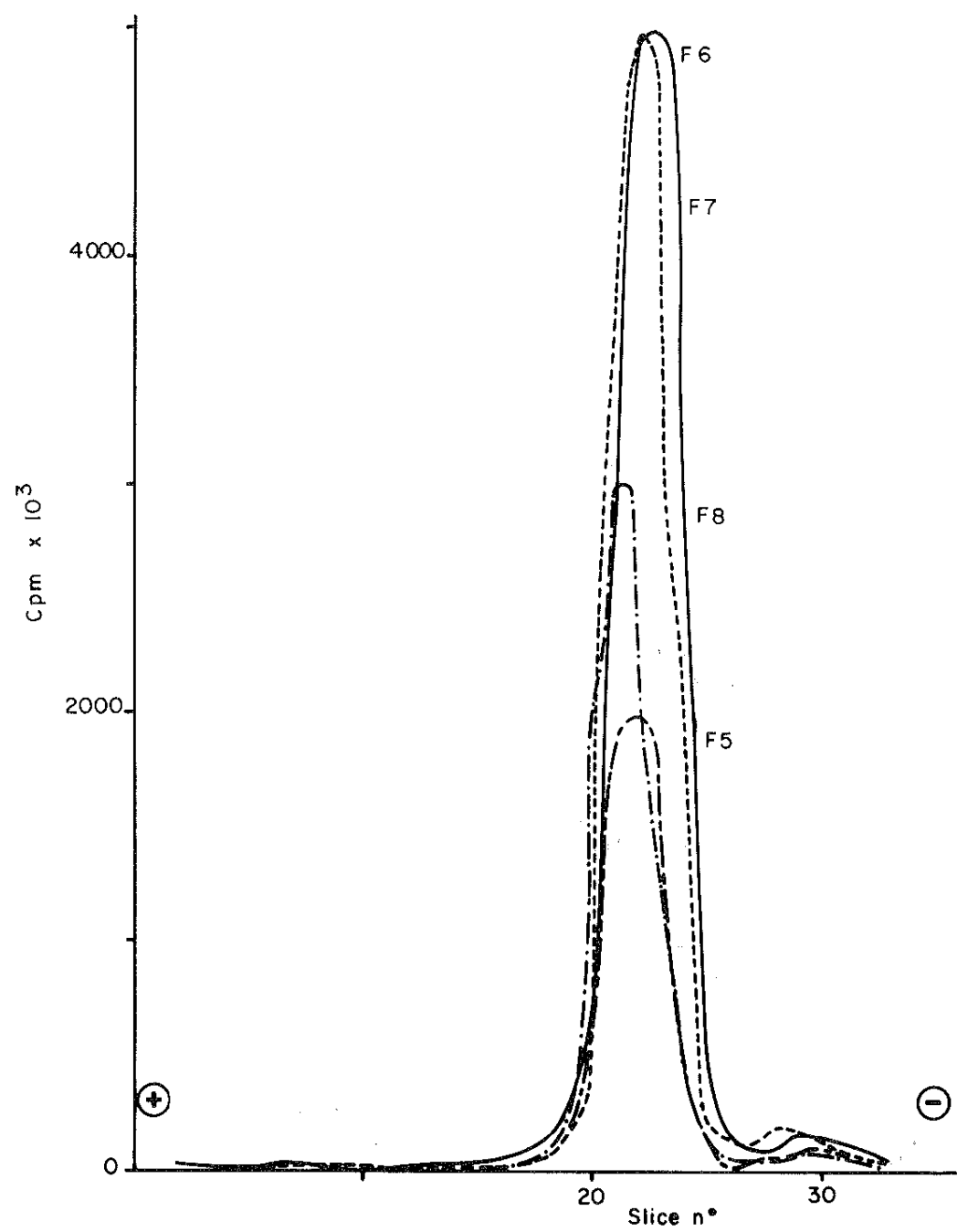

FIG. 4. Radioactive profiles of s-Gn-RH-LH-20 fractions after polyacrylamide gel electrophoresis at $7.5 \% 2.5 \mathrm{~mA}$ per tube $-4 \mathrm{hr}$ migration.

described in the same species and same strain (Breton et al., 1983). There was no statistical variation between the plasma $\mathrm{GtH}$ levels of fish taken at the end of vitellogenesis and those undergoing ovulation (5 $\mathrm{ng} / \mathrm{ml}$ ), a sharp increase occurred in recently ovulated, nonstripped animals (12 $\mathrm{ng} / \mathrm{ml}$ ), and levels returned to basal levels ( 2 ng or less) 1 month after ovulation. The pituitary GtH increased significantly from the end of vitellogenesis to maturation. It remained stable during maturation and ovulation but sharply decreased after ovulation.
At the end of vitellogenesis the total brain Gn-RH content was $8.94 \pm 0.76 \mathrm{ng} /$ brain $(n=8)$. It significantly increased up to $15 \mathrm{ng} / \mathrm{brain}$ when fish possess oocytes

TABLE 2

EVOLUTION OF THE IMMUNOAFFINITY OF THE Labeled s-Gn-RH with the Time of Preservation

\begin{tabular}{lrrrrrrr}
$\begin{array}{c}\text { Days of } \\
\text { preservation }\end{array}$ & 0 & 3 & 6 & 9 & 17 & 30 \\
\hline $\begin{array}{l}\text { munoactivity in } \\
\text { \% of binding ' }\end{array}$ & 78 & 74.2 & 83.4 & 77 & 73.4 & 84.2
\end{tabular}

Note. Antibody was used at a 1:1000 final dilution. 
TABLE 3

INTRA- AND INTERASSAY VARIABITITY

\begin{tabular}{cccccc}
\hline & \multicolumn{2}{c}{ Intraassay variability } & & \multicolumn{2}{c}{ Interassay variability } \\
\cline { 2 - 3 } Sample number & Gn-RH/ng per brain & CV \% & & Gn-RH/ng per brain & CV \% \\
\hline 1 & 1.946 & 6.3 & 1.758 & 22 \\
2 & 3.42 & 3.5 & 3.668 & 24.6 \\
3 & 1.339 & 7.5 & 1.617 & 29.4 \\
4 & 1.70 & 28 & 2.37 & 34.3 \\
5 & 0.23 & 56.8 & 2.20 & 64.0 \\
\hline
\end{tabular}

Note. Intraassay variability was determined measuring five different samples in 10 replicates within the same assay. For the interassay variability, the former assay was repeated on five consecutive days.

with germinal vesicles at their periphery just prior to the onset of maturation. It did not vary during maturation and ovulation, as did blood GtH concentrations, and began to decrease after ovulation to return to values close to $10 \mathrm{ng} / \mathrm{brain} 1$ month after, and less than $5 \mathrm{ng} 2$ months later. The general profile of $\mathrm{Gn}-\mathrm{RH}$ brain content roughly followed that of the pituitary $\mathrm{GtH}$ contents (Fig. 5).

Pituitary Gn-RH levels were lower than those of the brain. From the end of vitellogenesis until oocytes were at the germinal vesicle (VG) stage, the pituitary Gn-RH content appeared to rise from $1.58 \pm 0.69$ $(n=8)$ to $3.25 \pm 0.7(n=5) \mathrm{ng} /$ pituitary. In fishes beginning maturation, it significantly decreased to $1.51 \pm 0.33(n=8, P$ $<0.05)$, and rose in ovulating and recently ovulated fish $(P<0.01)$, in which it reached its maximum values at the same time as the plasma GtH levels. It returned to basal values 1 month after ovulation.

There was a positive and significant correlation between the pituitary Gn-RH and $\mathrm{GtH}$ levels in fish which had not yet begun maturation [i.e., end of germinal vesicle (FV) and VG stages] $(r=+0.81, P<0.01$, $n=13$ ), as well as in fish 1 month after ovulation $(r=0.89, P<0.01, n=21$ ). These two values were, however, not correlated in fish in active maturation and ovulation. On the contrary, these were the only phases during which pituitary Gn-RH and blood GtH concentration were positively correlated $(r=+0.89, P<0.01, n=12)$. Brain Gn-RH and plasma GtH were never correlated at any stage of the periovulatory period, but brain $\mathrm{Gn}-\mathrm{RH}$ and pituitary GTH were correlated before the bcginning of oocyte maturation ( $r=0.55$ with a $5 \%$ level of significance).

\section{DISCUSSION}

In this work we have developed a radioimmunoassay for the measurement of immunoreactive Gn-RH-like material in the brain and in the pituitary gland of salmonids and applied it to the determination of GnRH variations during the periovulatory period in the brown trout.

The amino acid composition (Breton et $a l ., 1984)$ and the elution profile obtained after HPLC lead to the conclusion that our Gn-RH preparation was homogeneous and corresponds to the formula established by Sherwood et al. (1983). Its biological activity in testosterone-implanted juvenile brown trouts is similar to that of $\mathrm{LH}-\mathrm{RH}$ in the juvenile rainbow trout (Crim and Evans, 1980), in the same concentration range. It is possible that only higher dosages are able to stimulate GtH secretion, as in mammals where native LH-RH is rapidly degraded by peptidase, as opposed to its analogs.

Evidence for a relationship between the 


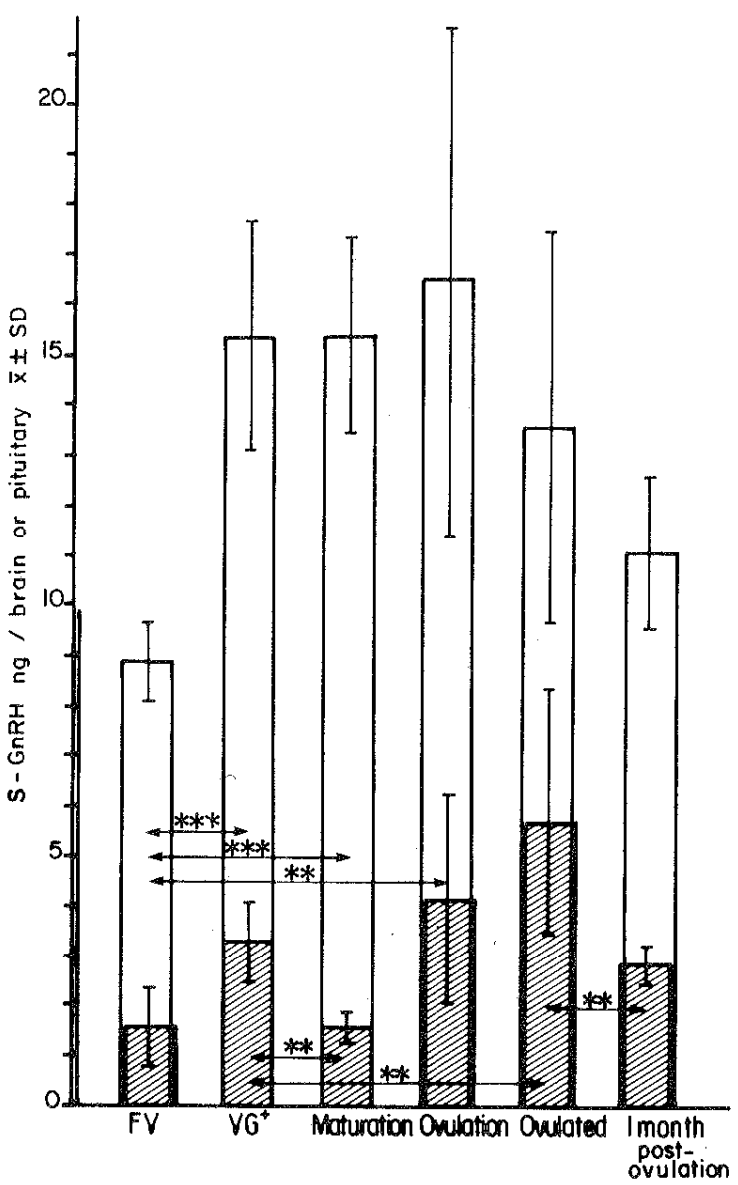

FIG. 5. Evolution of brain (open bars) and pituitary (hatched bars) Gn-RH contents during the periovulatory period in the brown trout. FV, end of vitellogenesis germinal vesicle in the center of the oocyte; VG, germinal vesicle at the periphery of the oncyte; maturation, oocyte entering and during maturation; ovulated, ovulations were detected twice a week, i.e, between 0 and 3 after ovulation.

newly synthesized s-Gn-RH and immunologically similar trout peptides has been obtained by immunohistochemistry. The localization of the immunoreactive structures in the trout brain is consistent with what is known in other species concerning regulation of gonadotropin secretion by the central system (Munz et al., 1982; Kah et al., 1985). At the level of the pituitary, the fibers reacting to anti-s-Gn-RH have a repartition similar to that described previously using antibodies to LH-RH (Dubois et al., 1979). This indicates that an immunoreactive-like s-Gn-RH substance is present in the brain and the pituitary of the trout. This has also been demonstrated after immunoassay and HPLC studies on rainbow trout brain extracts (Sherwood et al., 1984) which contain a peptide chromatographically and immunologically identical to salmon s-Gn-RH. Our results confirm the immunological identity between brown trout $\mathrm{Gn}-\mathrm{RH}$ and s-Gn-RH, as indicated by competitive studies.

Our Gn-RH does not specifically cross react with antibodies raised against mammalian and chicken Gn-RH, and the binding of s-Gn-RH to its antibodies is not specifically complete by $\mathrm{LH}-\mathrm{RH}$ and D-Ala-DesGly ${ }^{6} \mathrm{LH}-\mathrm{RH}$. Although this seems to indicate that our system does not specifically recognize these different forms of $\mathrm{LH}-\mathrm{RH}$, it remains possible that we could measure other forms of salmon $\mathrm{Gn}-\mathrm{RH}$, with similar immunoreactivity, as demonstrated after running rainbow trout brain extracts in HPLC (Sherwood et al., 1984).

After labeling, the electrophoretic purification step increases by about $20 \%$ the immunoactivity of the labeled s-Gn-RH; since electrophoretic profile shows no degradation of the molecule, it can be postulated that rather than the elimination of degraded forms of s-Gn-RH, this step allows the separation of labeled and unlabeled s-Gn-RH, as already suggested for insulin (Berson and Yalow, 1966) and LH-RH (Caraty et $a l ., 1980)$, for example. This profile, as well as the result obtained after enzymatic degradation of the peptide, demonstrates the suitability of the iodination procedure for obtaining monoiodo s-Gn-RH.

There is very little information concerning the activity of the Gn-RH system in the fish brain in relation to that of the pituitary gonadotropic function. Cytological studies have shown that some brain nuclei exhibit variations related to the reproductive cycle (Peter, 1970); nevertheless, there is no evidence that these nuclei contain Gn-RH. Several studies have also reported variations in the ultrastructural as- 
pects of the neurosecretory fibers innervating the gonadotrophs at the time of ovulation (Ekengren and Terlou, 1978; Knowles and Vollrath, 1966). At the quantitative level, the only available data have been obtained using heterologous radioimmunoassay (Dufour et al., 1982; Idler and Crim, 1981; Schreibman et al., 1983), and there has been no direct and specific measurement of brain and pituitary Gn-RH correlated with $\mathrm{GtH}$ levels in fish. This work shows, for the first time, that during the periovulatory period, the slow, prolonged increases in blood and pituitary GtH levels leading to ovulation are associated with a similar increase in the total Gn-RH content of the brain and pituitary in brown trout, and especially in the brain, which contains twice as much as Gn-RH as the pituitary.

The variations in the pituitary are not totally parallel to those of the brain. There is a decrease in the pituitary Gn-RH content in fish undergoing maturation when estradiol levels are lowest (Breton et al., 1983) and $17 \alpha$-hydroxy $20 \beta$-dihydroprogesterone has just begun to increase (Fostier and Jalabert, 1982; Scott et al., 1983), which could mean that estradiol exerts a negative feedback on both brain and pituitary Gn-RH with Gn-RH being released from the pituitary only when estradiol levels reach their minimum values. This decrease in pituitary Gn-RH content may be linked to the stimulation of $\mathrm{GtH}$ secretion to induce maturation. This hypothesis could explain the existence of a correlation between pituitary Gn-RH and plasma GtH during this event. It must be emphasized that it is only during this period that the plasma GtH secretion follows a circadian rhythm in the trout (Zohar et al., 1982). Perhaps Gn-RH would follow the same rhythm. On the contrary, before and after ovulation, during which time $\mathrm{GtH}$ secretion is pulsatile (Zohar et al., 1982), there is no correlation between pituitary Gn-RH and plasma GtH, although the pituitary Gn-RH is correlated with the pituitary GtH.
Although the brain Gn-RH content profile varies with the pituitary $\mathrm{GtH}$ content, these two parameters are not correlated as well as Gn-RH and plasma GtH, suggesting that the increase in brain $\mathrm{Gn}-\mathrm{RH}$ is related to a Gn-RH system closely related with maturation and ovulation. Immunoreactive material was found in many areas of the central nervous system and in the hypothalamopituitary complex. It is clear that the measurement of the total brain Gn-RH content partially reflects possible variations in specialized regions concerned with maturation and ovulation (i.e., the exact role of the different Gn-RH systems in the fish brain is still unknown concerning their control of maturation-ovulation or the acquisition of a sexual behavior, for example). The use of immunocytochemical techniques will be very helpful in the future in recognizing the Gn-RH systems and differentiating between them for the measurement of their Gn-RH content during typical stages of the reproductive cycle. Nevertheless, in the absence of a portal system allowing the determination of the Gn-RH directly supplying the pituitary gland, and as a first approach, the measure of the pituitary Gn-RH content appears to be a good index of the gonadotropic-releasing activity reaching the gonadotrophs in the trout.

\section{ACKNOWLEDGMENTS}

We are very grateful to Mrs. E. Sambroni for her technical assistance, Mrs. D. Bouix and Miss P. Provost for typing, and Dr. Paul Copeland for reviewing the manuscript. We thank Dr. Caraty and Dr. Dubois for their advice, and Dr. Hombrados, who performed the amino acid analysis. The antibodies against LHRH were kindly supplied by Dr. Dubois, and the antichicken LH-RH by Dr. J. A. King. This work was supported by the INRA (Institut National de la Recherche Agronomique).

\section{REFERENCES}

Berson, S., and Yalow, R. S. (1966). Iodo insulin used to determine specific activity of iodine 131 . Science (Washington, D.C.) 132, 205-206.

Breton, B., Fostier, A., Zohar, Y., Le Bail, P. Y., and 
Billard, R. (1983). Gonadotropine glycoprotéique et oestradiol-17 $\beta$ pendant le cycle reproducteur chez la Truite fario (Salmo trutta) femelle. Gen. Comp. Endocrinol. 49, 220-331.

Breton, B., Kann, G., Burzawa-Gerard, E., and Billard, R. (1971). Dosage radioimmunologique d'une hormone gonadotrope de Carpe (Cyprinus carpio L). C.R. Acad. Sci. Ser. D 272, 15151517.

Breton, B., Motin, A., Kah, O., Le Men, F., Geoffre, S., Precigoox, G., and Chambolle, P. (1984). Dosage radioimmunologique homologue d'un facteur hypophysaire de stimulation de la fonction gonadotrope hypophysaire de Saumon s-GnRH. C.R. Acad. Sci. Paris Ser. D 249, 383-387.

Breton, B., and Weil, C. (1973). Effets de LH/FSHRH synthétique et d'extraits hypothalamiques de Carpe sur la sécrétion d'hormone gonadotrope in vivo chez la Carpe (Cyprinus carpio L.). C.R. Acad. Sci. Ser. D 277, 2061-2064.

Breton, B., Weil, C., and Jalabert, B. (1972). Activité réciproque des facteurs hypothalamiques de Bélier et de poissons téléostéens sur la sécrétion in vitro des hormones gonadotropes c-HG et o- $\mathrm{LH}$ respectivement par des hypophyses de Carpe et de Bélier. C.R. Acad. Sci. Paris Ser. D 274, 2530-2533.

Caraty, A., de Reviers, M. M., Pelletier, J., and Dubois, M. P. (1980). Reassessment of LRF radioimmunoassay in the plasma and hypothalamic extracts of rats and rams. Reprod. Nutr. Dev. 20, 1489-1501.

Crim, L. W., and Evans, D. M. (1980). LH-RH-stimulated gonadotropin release from the rainbow trout pituitary gland: An in vitro assay for detection of teleost gonadotropin-releasing factor(s). Gen. Comp. Endocrinol. 40, 283-290.

Crim, L. W., and Evans, D. M. (1981). Onset of gonadotropic hormone accumulation in the immature trout pituitary gland in response to estrogen and aromatisable androgen steroid hormones. Gen. Comp. Endocrinol. 44, 374-381.

Dubois M. P., Billard, R., Breton, B., and Peter R. E. (1979). Comparative distribution of somatostatin, LH-RH, neurophysin and endorphin in the rainbow trout an immunological study. Gen. Comp. Endocrinol. 37, 220-232.

Dufour, S., Pasqualini, C., Kerdelhue, B., and Fontaine, Y. A. (1982). Présence and distribution of radioimmunoassayable $\mathrm{LH}-\mathrm{RH}$ in the european ell Anguilla anguilla. Neuropeptides 3, 159-171.

Ekengren, B., and Terlou, M. (1978). Hypothalamic centers and innervation of the hypophysis in Atlantic salmon (Salmo salar) and the rainbow trout (Salmo gairdneri). Ann. Biol. Anim. Biochim. Biophys. 18, 837-842.
Fostier, A., and Jalabert, B. (1982). Physiological basis of practical means to induce ovulation in fish. In "Reproductive Physiology of Fish" (C. J. J. Richter and H. J. Th. Goos, eds.), pp. 164-173. Pudoc, Wageningen.

Idler, D. R., and Crim, L. W. (1981). Gonadotropinreleasing factor(s) (GtH-RF) from hypothalamus of winter flounder. Abstract, "Ninth Symposium on Comparative Endocrinology," 7-11 Décember, Hong Kong.

Jalabert, B., and Breton, B. (1980). Evolution de la gonadotropine t-GtH après l'ovulation chez la Truite arc-en-ciel Salmo gairdneri $R$. et influence de la rétention des ovules. C.R. Acad. Sci. Paris Ser. D 290, 799-801.

Kah, O., Chambolle, P., Dubourg, P., and Dubois, M. P. (1984). Immunocytochemical localization of luteinizing hormone-releasing hormone in the brain of the goldfish Carassius auratus. Gen. Comp. Endocrinol. 53, 107-115.

Kah, O., Breton, B., Dulka, J. G., Nunez-Rodriguez, J., Peter, R. E., Rivier, J. J., Vale, W. W. (1985). A reinvestigation of the Gn- $\mathrm{RH}$ (Gonadotrophinreleasing hormone) systems in the goldfish brain using antibodies to salmon Gn-RH. Cell Tis. Res. in press.

King, J, A., and Millar, R. P. (1979). Heterogeneity of vertebrate luteinizing-hormone-releasing hormone. Science (Washington, D.C.) 206, 67-69.

King, J. A., and Millar, R. P. (1980). Comparative aspects of luteinizing hormone-releasing hormone structure and function in vertébrate phylogeny. Endocrinology 106, 707-717.

Knowles, F, and Vollrath (1966). Neurosecretory innervation of the pituitary of the eels Anguilla and conger. II. The structure and innervation of the pars distalis at different stages of the life cycle. Philos. Trans. R. Soc. London, Ser. B 250, 329342.

Munz, H., Claas, B., Stumpf, W. E., and Jennes, L. (1982). Centrifugal innervation of the retina by luteinizing hormone-releasing hormone (LH-RH) immunoreactive telencephalic neurons in teleostean fishes. Cell. Tissue Res. 222, 313-323.

Peter, R. E. (1970). Hypothalamic control of thyroid gland activity and gonadal activity in the goldfish Carassius auratus. Gen. Comp. Endocrinol. 14, 334-356.

Schreibman, M. P., Halpern-Seibold, L., Ferin, M., Margolis-Kazan, H., Goos H. J.Th. (1983). The effects of hypophysectomy and gonadotropin administration on the distribution and quantity of LH-RH in the brains of platyfish: A combined immunocytochemistry and radioimmunoassay study. Brain Res. 267, 293-300.

Scott, A. P., Sumpter, J. P., and Hardiman, P. A. 
(1983). Hormone changes during ovulation in the rainbow trout (Salmo gairdneri Richardson). Gen. Comp. Endocrinol. 49, 128-134.

Sherwood, N., Eiden, L., Brownstein, M., Spiess, J., Rivier, J., and Vale, W. (1983). Characterization of a teleost gonadotropin-releasing hormone. Proc. Natl. Acad. Sci. USA 80, 2794-2798.

Sherwood, N. M., Harvey, B., Brownstein, M. J., and Eiden, L. E. (1984). Gonadotropin-releasing hormone $(\mathrm{Gn}-\mathrm{RH})$ in striped Mullet (Mugil ce- phalus) Milkfish (Chanos chanos), and rainbow trout (Salmo gairdneri): Comparison with salmon Gn-RH. Gen. Comp. Endocrinol. 55, 174-181.

Zohar, Y., Breton, B., and Fostier, A. (1982). Gonadotropic function during the reproductive cycle of the female rainbow trout, Salmo gairdneri, in relation to ovarian steroid secretion: in vivo and in vitro studies. In "Reproductive Physiology of Fish. (C. J. J. Richter, H. J.Th. Goos, eds.), pp. 14-18. Pudoc, Wageningen. 